\title{
Influence of Season and Cropping System on Occurrence of Cowpea Diseases in Uganda
}

\author{
R. Edema, Former Graduate Student, and E. Adipala, Plant Pathologist, Department of Crop Science, Makerere \\ University, P.O. Box 7062, Kampala, Uganda; and D. A. Florini, Plant Pathologist, International Institute of Tropi- \\ cal Agriculture, Oyo Road, PMB 5320, Ibadan, Nigeria
}

\begin{abstract}
Edema, R., Adipala, E., and Florini, D. A. 1997. Influence of season and cropping system on occurrence of cowpea diseases in Uganda. Plant Dis. 81:465-468.

An on-farm survey was conducted for two seasons (first and second rains of 1994) to determine influence of season and cropping systems on occurrence of cowpea (Vigna unguiculata) diseases in Uganda. Viral diseases were widespread in both seasons but were more severe in the intercropped than in the nonintercropped cowpea. In contrast, scab, rust, and powdery mildew were less common and less severe when cowpea was grown in intercrops. High plant populations favored scab and anthracnose, but viral diseases were more severe under low plant populations. Higher incidence and severity of viral diseases, anthracnose, and scab were recorded during the first (wetter) season than during the second (drier) season. Disease level varied considerably among the common cultivars, but these differences may have been influenced by environmental differences.
\end{abstract}

In Uganda, cowpea (Vigna unguiculata (L.) Walp.) is traditionally grown by smallholder farmers whose farm holdings average 1 to 7 ha per family, of which 0.05 to 0.76 ha is cropped with cowpea (2,13). Most of the crop is grown during the shorter rainy season (August to October) and mostly monocropped. Recently, there has also been increased cultivation of the crop during the longer rainy season (March to June), largely in response to the high market demand for the crop (13).

Cowpea is often grown in mixed stands with sorghum (Sorghum bicolor (L.) Moench), greengram (Vigna aureus L.), maize (Zea mays L.), pigeonpea (Cajanus cajan (L.) Millsp.), and cassava (Manihot esculenta Crantz) (13). Although there is a wealth of literature on the effect of intercropping on legume pests and yield $(9,12,15)$, literature is largely lacking on diseases, especially under farmer conditions. The most common diseases of cowpea in Uganda include cowpea aphid-borne mosaic (caused by the cowpea aphid-borne mosaic potyvirus), bacterial blight (Xanthomonas vignicola and Pseudomonas syringae), rust (Uromyces phaseoli (Pers.)

Corresponding author: E. Adipala

E-mail: acss@starcom.co.ug

Accepted for publication 27 January 1997.

Publication no. D-1997-0320-06R

(C) 1997 The American Phytopathological Society
Wint.), zonate leaf spot (Ascochyta phaseolorum Sacc.), white zonate leaf spot (Dactuliophora tarri Leakey), false rust (Synchytrium dolichi (Cooke) Gaum), anthracnose (Colletotrichum lindemuthianum (Sacc. \& Magnus) Bri. \& Car.), scab (Sphaceloma sp.), gray leaf mold (Cercospora canescens Ellis \& G. Martin), foot rot (Fusarium solani (Mart.) Sacc.), pod mold (Cladosporium vignae M.W. Gardner), Phyllosticta leaf spot (Phyllosticta phaseolina Sacc.), powdery mildew (Erysiphe polygoni DC.), and Fusarium wilt ( $\mathrm{Fu}$ sarium oxysporum f. sp. tracheiphilum (E.F. Sm.) W.C. Snyder \& H.N. Hans.) (3).

The objectives of this study were to determine the seasonal occurrence of cowpea diseases and to examine the effect of cropping systems on the incidence and severity of diseases in farmers' fields.

\section{MATERIALS AND METHODS}

Site selection. Five districts were visited during the first rainy season of 1994 (March to June) and during the second rainy season (September to November) of the same year. These districts were selected because they are the major cowpea growing areas of Uganda (13) and they varied in agroecologies (Table 1). Data were collected from a sample of 10 farmers per county drawn from one county each of Arua, Lira, Tororo, and Nebbi districts; two each of Kumi and Pallisa; and three of Soroti district. In each county, the study area consisted of two parishes randomly chosen from a list of four to six parishes per county. A list of farmers was obtained for each parish, and 10 farmers were selected per county using random numbers.
Tororo and Lira districts were surveyed September to November, the traditional planting dates for these districts. Thus, a total of 90 fields was assessed during the first season and 110 during the second season.

Data collection and analysis. The severity and incidence of the major diseases affecting cowpea (3-5) were assessed on 10 plants chosen at random by walking in a zig zag manner, and spaced $10 \mathrm{~m}$ apart. Disease severity was rated using a modified scale of Horsfall and Barratt (6) with $0,1,5,10,25,50,75$, and $100 \%$ of plant area affected (PAA), while disease incidence was the percentage of 10 plants showing symptoms. The cropping systems (mixed cropping versus monocropping) and cultivars grown were noted. Mean plant population was obtained by averaging the plant population in four quadrants $(1 \times 1 \mathrm{~m})$.

Disease samples were taken to the Plant Pathology Laboratory at Makerere University for confirmation of symptoms and causal pathogens. For viral symptoms, serological tests were carried out at the cassava section of the Namulonge Agricultural and Animal Production Research Institute, Uganda. This was done only for the cowpea aphid-borne mosaic potyvirus (CAMV) and cucumber mosaic cucumovirus (CMV). Data analyses were conducted using the MSTAT-C computer package (Russel D. Freed, Michigan State University, East Lansing). Analysis of variance (ANOVA) was used to test variation of disease levels with season and cropping system. Where the $F$ statistics were significant, means were separated using the Least Significant Difference (LSD) test at $5 \%$ probability level. Severity and incidence of different diseases were also related to plant population by correlation analysis (14).

\section{RESULTS AND DISCUSSION}

Higher incidence and severity of viral diseases (caused by CAMV and CMV), anthracnose, and scab were recorded during the first (wetter) season than during the second (drier) season (Table 2). This was expected, as most fungal disease epidemics are favored by humid conditions (16). For viral diseases, we expected higher infection during the drier second rains than during the long and wetter first rains because of the close relationship between 
aphid and viral incidences. However, aphid infestation was higher in the first rather than the second rains, and viral disease incidence was greater during the first season. We suspect that this was due to the short dry spells that occurred during the first season.

The present data and others (5) suggest a higher level of scab during the wetter (first) rains than the drier (second) rains. However, experiments over the past 2 years at Kabanyolo, Uganda, documented the contrary (7). In the case of false rust, the pathogen Synchytrium dolichi is an obligate parasite and may have been able to build up to higher levels during the second rains. In a previous study conducted at Kabanyolo, although the first rain crop had low incidence of false rust, the second rain crop was devastated by the disease (4). Common rust ( $U$. phaseoli) was not encountered during the first rains but was common during the second rains (Table 2). The fact that disease incidence and severity varied from season to season is indicative of the role rainfall, temperature, humidity, and inoculum level play in determining disease occurrence.

Except for viral diseases and Cercospora (Cercospora canescens and C. cruenta) and Dactuliophora leaf spots (Dactuliophora tarri), disease incidence and severities were generally lower in intercropped than in sole cropped fields (Tables 3 and 4). The influence of intercropping in reducing disease and pest incidence has been reported $(8,9,11,15)$, a factor probably contributing to the widespread use of intercropping in subsistence farming. Under natural farming conditions, i.e., without pesticide control, low disease probably occurred because of the ecological balance between host, pest, and environment (9). In this study, disease data on intercropping are pooled from different crop combinations. Therefore, the effects of specific cropping combinations (systems, spatial arrangement) on disease occurrence are not known and require investigation. Moreover, different pathogens behave differently under different crop combinations (10).

Slightly higher incidence and severity of anthracnose and scab were associated with

Table 1. Location, temperature, mean annual rainfalls, altitudes, and cropping systems of the areas visited during the survey ${ }^{\mathrm{a}}$

\begin{tabular}{|c|c|c|c|c|c|}
\hline Area of survey & Grid reference & $\begin{array}{l}\text { Temperature }\left({ }^{\circ} \mathbf{C}\right) \\
\text { (daily min-max) }\end{array}$ & $\begin{array}{l}\text { Mean annual } \\
\text { rainfall }(\mathbf{m m})\end{array}$ & Mean altitude (m) & Crops grown with cowpea \\
\hline $\begin{array}{l}\text { Arua }^{\mathrm{b}} \\
\left(\text { Okollo }^{\mathrm{c}}\right.\end{array}$ & $31^{\circ} 1^{\prime} \mathrm{E}, 2^{\circ} 7^{\prime} \mathrm{N}$ & $20.0-35.0$ & 875 & $610-742$ & Greengram, sorghum, cassava \\
\hline $\mathrm{Nebbi}^{\mathrm{b}}$ & & & & & \\
\hline $\begin{array}{l}(\text { Pakwach) } \\
\text { Kumi }^{\mathrm{c}}\end{array}$ & $31^{\circ} 3^{\prime} \mathrm{E}, 2^{\circ} 4^{\prime} \mathrm{N}$ & $22.5-35.0$ & 875 & $610-742$ & Cassava, sorghum \\
\hline $\begin{array}{l}\text { (Bukedea \& Kumi) }^{\mathrm{c}} \\
\text { Soroti }^{\mathrm{b}}\end{array}$ & $33^{\circ} 7^{\prime} \mathrm{E}, 1^{\circ} 5^{\prime} \mathrm{N}$ & $17.5-27.5$ & 1,000 & $914-1,066$ & Maize, cassava, sorghum \\
\hline $\begin{array}{l}\text { (Soroti, Amuria \& Usuk) }^{\mathrm{c}} \\
\text { Pallisa }^{\mathrm{b}}\end{array}$ & $33^{\circ} 6^{\prime} \mathrm{E}, 1^{\circ} 8^{\prime} \mathrm{N}$ & $17.5-27.5$ & 1,000 & $762-1,066$ & Greengram, cassava, sorghum \\
\hline $\begin{array}{l}\text { (Butebo \& Pallisa) }^{\mathrm{c}} \\
\text { Tororo }^{\mathrm{d}}\end{array}$ & $33^{\circ} 6^{\prime} \mathrm{E}, 1^{\circ} 1^{\prime} \mathrm{N}$ & $17.5-27.5$ & 1,250 & $914-1,066$ & Maize, cassava \\
\hline $\begin{array}{l}\text { Lira }^{\mathrm{d}} \\
\text { Bunole }^{\mathrm{c}}\end{array}$ & $33^{\circ} 0^{\prime} \mathrm{E}, 0^{\circ} 10^{\prime} \mathrm{N}$ & $15.0-27.5$ & 1,250 & $1,066-1,219$ & Cassava \\
\hline$(\text { Erute })^{\mathrm{c}}$ & $32^{\circ} 9^{\prime} \mathrm{E}, 2^{\circ} 6^{\prime} \mathrm{N}$ & $15.0-33.0$ & 1,000 & $914-1,066$ & Greengram, pigeonpea, cassava \\
\hline
\end{tabular}

a Source: Atlas of Uganda, 1968. Department of Lands and Surveys, Entebbe, Uganda.

b District.

${ }^{\mathrm{c}}$ County.

${ }^{\mathrm{d}}$ Not visited in the first rains.

Table 2. Incidence ( $\% \pm$ SE) and severity ( $\% \pm$ SE) of different diseases observed during the two rainy seasons of 1994 in Uganda ${ }^{a}$

\begin{tabular}{lccr}
\hline & \multicolumn{2}{c}{ Season } & \\
\cline { 2 - 3 } Disease & $\begin{array}{c}\text { First rains } \\
\text { (March-May) }\end{array}$ & $\begin{array}{c}\text { Second rains } \\
\text { (Sept.-Dec.) }\end{array}$ & Mean \\
\hline Incidence & & & \\
$\quad$ Viral & $71.8 \pm 2.6$ & $40.5 \pm 2.4$ & 56.1 \\
Cercospora leaf spot & $29.9 \pm 2.8$ & $39.6 \pm 3.8$ & 34.7 \\
Anthracnose & $5.3 \pm 2.0$ & $0.1 \pm 0.7$ & 2.7 \\
Scab & $8.6 \pm 1.5$ & $4.6 \pm 1.0$ & 6.6 \\
False rust & $0.8 \pm 0.1$ & $5.8 \pm 1.1$ & 8.3 \\
Dactuliophora leaf spot & $6.3 \pm 1.4$ & $7.1 \pm 1.4$ & 6.7 \\
Powdery mildew & $1.1 \pm 0.6$ & $1.2 \pm 0.3$ & 1.1 \\
Rust & $0.0 \pm 0.0$ & $2.2 \pm 0.8$ & 1.1 \\
Severity & $12.5 \pm 0.9$ & $5.4 \pm 0.5$ & \\
Viral & $7.0 \pm 1.0$ & $5.2 \pm 0.5$ & 6.1 \\
Cercospora leaf spot & $2.2 \pm 0.7$ & $0.5 \pm 0.2$ & 1.4 \\
Anthracnose & $1.5 \pm 0.3$ & $0.7 \pm 0.2$ & 1.1 \\
Scab & $1.4 \pm 0.0$ & $1.0 \pm 0.2$ & 1.2 \\
False rust & $0.3 \pm 0.1$ & $0.5 \pm 0.2$ & 0.4 \\
Dactuliophora leaf spot & $0.2 \pm 0.1$ & $0.2 \pm 0.1$ & 0.2 \\
Powdery mildew & $0.0 \pm 0.0$ & $2.3 \pm 1.4$ & 1.2 \\
Rust & & & \\
\hline
\end{tabular}

${ }^{a}$ Severity is percent plant area affected; disease incidence is the percentage of 10 plants showing symptoms.

b Mean of 90 fields.

${ }^{c}$ Mean of 110 fields.
Table 3. Influence of two cropping systems practiced in the major cowpea growing areas of Uganda on the incidence (\%) and severity (\%) of different diseases of cowpea during the first rainy season of $1994^{\mathrm{a}}$

\begin{tabular}{lccc}
\hline & \multicolumn{2}{c}{ Cropping system } & \\
\cline { 2 - 3 } Disease & Intercrop & Monocrop $^{\mathbf{b}}$ & Mean \\
\hline Incidence & & & \\
$\quad$ Viral & 76.7 & 72.2 & 74.4 \\
Cercospora leaf spot & 29.5 & 27.7 & 28.6 \\
Anthracnose & 0.0 & 23.6 & 11.8 \\
Scab & 0.0 & 18.4 & 9.2 \\
False rust & 0.2 & 0.0 & 0.1 \\
Dactuliophora leaf & 1.2 & 4.9 & 3.0 \\
$\quad$ spot & & & \\
Powdery mildew & 0.3 & 2.3 & 1.3 \\
Severity & & & \\
Viral & 14.90 & 11.90 & 13.40 \\
Cercospora leaf spot & 7.10 & 5.20 & 6.20 \\
Anthracnose & 0.00 & 5.40 & 2.70 \\
Scab & 0.00 & 3.20 & 1.60 \\
False rust & 0.04 & 0.00 & 0.02 \\
Dactuliophora leaf & 0.20 & 0.60 & 0.40 \\
$\quad$ spot & & & \\
Powdery mildew & 0.03 & 0.40 & 0.20 \\
\hline Severity is percnt & &
\end{tabular}

a Severity is percent plant area affected; disease incidence is the percentage of 10 plants showing symptoms.

${ }^{b}$ Mean of 10 plants per field in 20 fields for severity; mean of 20 fields for incidence. 
higher plant populations (Table 5). In contrast, slightly higher severity of viral diseases was associated with low cowpea populations. Plant population is known to modify microclimate under field conditions (1). It is probable that the high incidence and severity of scab and anthracnose were due to a relatively humid microclimate, which favors epidemics of these diseases (16). Higher plant populations are also known to reduce aphid infestation (12). Some of the virus diseases of cowpea, such as CAMV and CMV, are transmitted by aphids. It is probable that the low viral disease incidence under high plant population was due to the unfavorable microclimate created for the aphids in the intercrops (12).
During the first rains, significantly higher incidences of anthracnose $(P=$ $0.006)$, scab $(P=0.001)$, and powdery mildew $(P=0.05)$ were observed on the cultivar Ebelat, while higher incidence of Dactuliophora leaf spot $(P=0.001)$ occurred on the cultivar Icirikukwai (Tables 6 and 7$)$. In contrast, during both rainy seasons, viral diseases were significantly $(P=$ $0.001)$ more severe on cultivars Amul and Osu (and Apei in the second rains), but Cercospora leaf spot was significantly $(P=$ 0.001 ) more severe on cultivars Osu and Icirikukwai, and in the second rains on Amul, Osu, and Kisyanka. The differences in resistance of these cultivars to the various diseases encountered may have contributed to variation in disease prevalence.
In most districts, farmers chose the varieties they grew based on aspects such as taste and early maturity. For example, in Pallisa district, farmers preferred the cultivar Ebelat, which has good market in the district. Thus, the disease levels on the various cultivars were not observed under the same environmental conditions or cropping system. These cultivars should, therefore, be screened under uniform and disease conducive conditions to confirm resistance.

The present study provides a general picture of occurrence of cowpea diseases in Uganda. More detailed investigations are needed to isolate effects of crop combinations. Information is also needed on the effect of plant densities and spatial ar-
Table 4. Influence of two cropping systems practiced in the major cowpea growing areas of Uganda on the incidence $(\%)$ and severity (\%) of different diseases of cowpea during the second rainy season of $1994^{\mathrm{a}}$

\begin{tabular}{lccc}
\hline & \multicolumn{2}{c}{ Cropping system } & \\
\cline { 2 - 2 } Disease & Intercrop & Monocrop & Mean \\
\hline Incidence & & & \\
Viral & 48.5 & 32.3 & 40.4 \\
Cercospora leaf spot & 47.8 & 32.5 & 40.2 \\
Scab & 0.0 & 13.4 & 6.7 \\
False rust & 0.2 & 5.8 & 3.0 \\
Dactuliophora leaf spot & 14.8 & 9.5 & 12.2 \\
Powdery mildew & 0.0 & 0.8 & 0.4 \\
Rust & 0.8 & 7.0 & 3.9 \\
Severity & & & \\
Viral & 7.7 & 3.1 & 5.4 \\
Cercospora leaf spot & 4.5 & 4.2 & 4.3 \\
Scab & 0.0 & 1.8 & 1.0 \\
False rust & 0.0 & 1.0 & 0.5 \\
Dactuliophora leaf spot & 1.0 & 1.1 & 1.1 \\
Powdery mildew & 0.0 & 0.1 & 0.04 \\
Rust & 0.1 & 7.8 & 3.9 \\
\hline
\end{tabular}

a Severity is percent plant area affected; disease incidence is the percentage of 10 plants showing symptoms.

b Mean of 10 plants per field in 20 fields for severity; mean of 20 fields for incidence.
Table 5. Correlation coefficients among disease incidence, severity, and plant population (number of plants $\mathrm{m}^{-2}$ )

\begin{tabular}{|c|c|c|c|c|}
\hline Disease & $\begin{array}{c}\text { Incidence } \times \\
\text { P1 }^{\mathrm{a}}\end{array}$ & $\begin{array}{c}\text { Severity } \times \\
\text { P1 }\end{array}$ & $\begin{array}{c}\text { Incidence } \times \\
\text { P2 }\end{array}$ & $\begin{array}{c}\text { Severity } x \\
\text { P2 }\end{array}$ \\
\hline \multicolumn{5}{|l|}{ First rains (March-May) } \\
\hline Viral & -0.15 & 0.11 & -0.01 & $-0.39 * * \mathrm{~b}$ \\
\hline Cercospora leaf spot & - & - & -0.07 & -0.09 \\
\hline Anthracnose & - & - & $0.40 * *$ & $0.40 * *$ \\
\hline Scab & - & - & $0.51^{* *}$ & $0.47 * *$ \\
\hline False rust & - & - & NS & NS \\
\hline Dactuliophora leaf spot & - & - & $0.28 *$ & $0.27 *$ \\
\hline Powdery mildew & - & - & NS & NS \\
\hline \multicolumn{5}{|l|}{ Second rains (Sept.-Dec.) } \\
\hline Viral & -0.03 & -0.01 & $-0.29 *$ & $-0.31^{*}$ \\
\hline Cercospora leaf spot & - & - & 0.01 & 0.25 \\
\hline Anthracnose & - & - & 0.06 & 0.07 \\
\hline Scab & - & - & $0.64 * * *$ & $0.62 * * *$ \\
\hline False rust & - & - & 0.09 & 0.04 \\
\hline Dactuliophora leaf spot & - & - & $-0.34 * *$ & $-0.37 * *$ \\
\hline Powdery mildew & - & - & NS & NS \\
\hline Rust & - & - & NS & NS \\
\hline
\end{tabular}

a P1 (7.4 to 20.4 plants $\mathrm{m}^{-2}$ and 8.3 to 22.2 plants $\mathrm{m}^{-2}$ during the first and second seasons, respectively) and $\mathrm{P} 2$ (3.5 to 13.3 plants $\mathrm{m}^{-2}$ and 6.0 to 16.6 plants $\mathrm{m}^{-2}$ during the first and second seasons, respectively) indicate plant population at early vegetation and maturity, respectively.

$\mathrm{b} *, * *, * * *$ indicate levels of significance at $P=0.05, P=0.01$, and $P=0.001$, respectively. Dashes $=$ absence of fungal diseases during early vegetation. NS = not significant.

Table 6. Incidence $(\%)$ and severity $(\%)$ of different diseases on four commonly grown cowpea varieties in Uganda during the first season of $1994^{\mathrm{a}}$

\begin{tabular}{|c|c|c|c|c|c|}
\hline \multirow[b]{2}{*}{ Disease } & \multicolumn{4}{|c|}{ Variety $^{b}$} & \multirow[b]{2}{*}{ Mean } \\
\hline & Amul & Osu & Icirikukwai & Ebelat & \\
\hline \multicolumn{6}{|l|}{ Incidence } \\
\hline Viral & 80.3 & 73.0 & 61.3 & 61.8 & 69.1 \\
\hline Cercospora leaf spot & 17.7 & 41.3 & 35.1 & 33.3 & 31.9 \\
\hline Anthracnose & 0.0 & 0.0 & 0.0 & 6.3 & 1.6 \\
\hline Scab & 0.0 & 0.0 & 6.3 & 22.3 & 7.2 \\
\hline False rust & 0.0 & 0.3 & 0.0 & 0.0 & 0.1 \\
\hline Dactuliophora leaf spot & 0.7 & 1.7 & 19.3 & 6.7 & 7.1 \\
\hline Powdery mildew & 0.0 & 0.7 & 0.0 & 4.7 & 1.3 \\
\hline \multicolumn{6}{|l|}{ Severity } \\
\hline Viral & 12.1 & 17.7 & 8.6 & 7.8 & 11.6 \\
\hline Cercospora leaf spot & 2.0 & 12.3 & 10.2 & 4.9 & 7.3 \\
\hline Anthracnose & 0.0 & 0.0 & 0.0 & 0.8 & 0.2 \\
\hline Scab & 0.0 & 0.0 & 1.4 & 3.9 & 1.3 \\
\hline False rust & 0.0 & 0.3 & 0.0 & 0.0 & 0.1 \\
\hline Dactuliophora leaf spot & 0.3 & 0.1 & 0.1 & 0.8 & 0.3 \\
\hline Powdery mildew & 0.0 & 0.1 & 0.0 & 0.7 & 0.2 \\
\hline
\end{tabular}

a Severity is percent plant area affected; disease incidence is the percentage of 10 plants showing symptoms.

b Mean of 10 plants per field in 10 fields for severity; mean of 90 fields for incidence. 
Table 7. Incidence (\%) and severity $(\%)$ of different diseases on five commonly grown cowpea varieties in Uganda during the second season of $1994^{\mathrm{a}}$

\begin{tabular}{|c|c|c|c|c|c|c|}
\hline \multirow[b]{2}{*}{ Disease } & \multicolumn{5}{|c|}{ Variety $^{b}$} & \multirow[b]{2}{*}{ Mean } \\
\hline & Amul & Osu & Ebelat & Apei & Kisyanka & \\
\hline \multicolumn{7}{|l|}{ Incidence } \\
\hline Viral & 51.3 & 45.7 & 35.5 & 47.3 & 29.0 & 41.8 \\
\hline Cercospora leaf spot & 48.0 & 47.7 & 24.3 & 6.7 & 40.7 & 33.5 \\
\hline Scab & 0.0 & 0.0 & 16.5 & 6.0 & 10.3 & 6.6 \\
\hline False rust & 0.3 & 0.0 & 0.0 & 6.3 & 11.7 & 3.7 \\
\hline Dactuliophora leaf spot & 11.7 & 18.0 & 0.0 & 2.3 & 19.0 & 10.2 \\
\hline Powdery mildew & 0.0 & 0.0 & 1.5 & 0.3 & 0.0 & 0.4 \\
\hline Rust & 1.7 & 0.0 & 0.0 & 0.0 & 14.0 & 3.1 \\
\hline \multicolumn{7}{|l|}{ Severity } \\
\hline Viral & 7.9 & 7.5 & 4.0 & 6.9 & 2.2 & 7.7 \\
\hline Cercospora leaf spot & 3.8 & 5.3 & 4.9 & 0.3 & 3.4 & 3.5 \\
\hline Scab & 0.0 & 0.0 & 2.1 & 1.0 & 1.6 & 0.9 \\
\hline False rust & 0.0 & 0.0 & 0.0 & 1.3 & 2.0 & 0.7 \\
\hline Dactuliophora leaf spot & 0.4 & 2.0 & 0.0 & 0.1 & 2.3 & 1.0 \\
\hline Powdery mildew & 0.0 & 0.0 & 0.1 & 0.1 & 0.0 & 0.1 \\
\hline Rust & 0.2 & 0.0 & 0.0 & 0.0 & 0.0 & 15.5 \\
\hline
\end{tabular}

a Severity is percent plant area affected; disease incidence is the percentage of 10 plants showing symptoms.

b Mean of 10 plants per field in 10 fields for severity; mean of 110 fields for incidence.

rangements on the different diseases. A clear understanding of the epidemiology of these diseases is critical in the development of an effective disease management package.

\section{ACKNOWLEDGMENTS}

The survey was financed by the Makerere University Cowpea Improvement Project under a Rockefeller Foundation Forum Grant RF 93040 \#13. Additional support to the first author was provided by the United States Agency for International Development (USAID) under the Agricultural Research and Training Programme at Makerere University, Uganda.

\section{LITERATURE CITED}

1. Adipala, E., Takan, J. P., and Ogenga-Latigo, M. W. 1995. Effect of plant density of maize on the progress and spread of northern leaf blight from Exserohilum turcicum infested residue source. Eur. J. Phytopathol. 101:2533

2. Dunbar, A. R. 1969. The Annual Crops of Uganda. East Africa Literature Bureau, Kampala.

3. Edema, R. 1995. Investigation into factors affecting disease occurrence and farmer control strategies on cowpea in Uganda. M.Sc. thesis. Makerere University, Kampala,
Uganda.

4. Edema, R., and Adipala, E. 1994. Cowpea disease: Part I. Control of false and brown rusts using benomyl and mancozeb. E. Afr. Agric. For. J. 60:311-318.

5. Emechebe, A. M. 1980. Scab disease of cowpea (Vigna unguiculata (L.) Walp.) caused by Sphaceloma a species of fungus. Ann. Appl. Biol. 96:11-16.

6. Horsfall, J. G., and Barratt, R. W. 1945. An improved grading system for measuring plant diseases. Phytopathology 35:655.

7. Iceduna, C. L., Adipala, E., and OgengaLatigo, M. W. 1994. Evaluation of 80 cowpea lines for resistance to Sphaceloma sp. Afr. Crop Sci. J. 2:207-214

8. Kato, D., Karel, A. K., and Ndunguru, B. J. 1980. Effect of insecticide spray on insect pests and yield of sorghum and simsim in pure stand and in intercropping. Pages 115116 in: Intercropping: Proc. Symp. Intercropping Semi-Arid Areas, 2nd.

9. Keswani, C. L., and Mreta, R. A. D. 1980. Effect of intercropping on the severity of powdery mildew on green-gram. Pages 110114 in: Intercropping. Proc. Symp. Intercropping Semi-Arid Areas, 2nd.

10. Moreno, R. A. 1979. Crop protection implications of cassava intercropping. Pages 113127 in: Intercropping with cassava: Proc. Int. Workshop, 1978.
11. Mukiibi, J. K. 1976. Possible relationship between intercropping and plant disease problems in Uganda. Intercropping in SemiArid Areas: Rep. Symp. Faculty of Agriculture, Forestry and Veterinary Science, University of Dar-es-salaam, 1976. J. H. Monyo, A D. R. Ker, and M. Campbell, ed. IDRC-076e, 45.

12. Ogenga-Latigo, M. W., Ampofo, J. K. O., and Baliddawa, C. W. 1992. Influence of maize row spacing on infestation and damage of intercropped beans. I. Incidence of aphids (Aphis fabae Scop.). Field Crops Res. 30:111121.

13. Sabiti, A. G., Nsubuga, E. N. B., Adipala, E., and Ngambeki, D. S. 1994. Socioeconomic aspects of cowpea production in Uganda: A rapid rural appraisal. Uganda J. Agric. Sci. 2:29-35.

14. Steele, R. G., and Torrie, J. H. 1980. Principles and Procedures of Statistics: A Biometrical Approach. 2nd ed. McGraw Hill, New York.

15. Van Rheenen, H. A., Hasselbach, O. E., and Muigai, S. G. 1981. The effect of growing beans together with maize on the incidence of bean diseases and pests. Neth. J. Plant Pathol 87:193-199.

16. Williams, R. J. 1975. Diseases of cowpea (Vigna unguiculata (L.) Walp.) in Nigeria. PANS 21:253-267. 